\title{
Reproductive biology of Amasonia obovata Gleason (Laminaceae)
}

\author{
Thays de Assis SCHVINN ${ }^{1}$, Anderson Fernandes de MIRANDA ${ }^{1}$, Celice Alexandre SILVA ${ }^{*}$ \\ 1 Universidade do Estado de Mato Grosso. Centro de Pesquisas, Estudos e Desenvolvimento Agro-Ambientais (CPEDA). Rodovia MT 358, km 7,5 Jd Aeroporto. 78300-000. \\ Tangará da Serra-MT, Brasil. \\ * Corresponding author: celicealexandre645@hotmail.com
}

\section{ABSTRACT}

Floral mechanisms that ensure seed production via autogamy are more likely to occur in species growing in environments where pollination is scarce. Amasonia obovata was studied in the State of Mato Grosso-Brazil, from 2009 to 2012, to analyze the morphological and reproductive characteristics, aside from investigating the association of the reproductive success with the pollinator frequency and identity. The flowering and fruiting of $A$. obovata was concentrated in a period of five months during the rainy season. The dichogamy in flowers of $A$. obovata is not clearly defined, since the sexual functions were overlapped in the male and female phases. The species is self-compatible and not apomictic. The fruiting percentage obtained by hand self-pollination did not differ from cross-breeding $(\mathrm{F}=0.74, \mathrm{P}=0.39)$. In the observations from 2010 to 2012 , a hummingbird (Thalurania furcata) legitimate visited $20-100 \%$ of the flowers in the male and female phases on different $A$. obovata plants. Due to the high frequency, this hummingbird was considered the single potential pollinator of the species. These findings show that a limited availability of pollinators may select for floral traits and plant mating strategies that lead to a system of self-fertilization.

KEYWORDS: Autogamy, floral morphology, flowering phenology, hummingbird

\section{Biologia reprodutiva em Amasonia obovata Gleason (Laminaceae)}

\section{RESUMO}

Mecanismos florais que garantem produção de sementes via autogamia, são mais prováveis de ocorrer em espécies que crescem em habitats onde a polinização é escassa. Amasonia obovata foi estudada na região sudoeste do estado de Mato Grosso, durante os anos de 2009 a 2012, e o estudo teve por objetivo analisar as características morfológicas, morfométricas e reprodutivas, além de associar o sucesso reprodutivo à frequência de polinizadores. A. obovata concentrou a floração e frutificação em um período de cinco meses, durante a estaçáo chuvosa. A dicogamia em flores de $A$. obovata não está claramente demarcada, já que as funções sexuais se sobrepóem nas fases masculina e feminina. A espécie é autocompatível e não apomítica. Os valores percentuais de frutificação obtidos na autopolinização manual não diferiram dos valores obtidos na polinização cruzada ( $\mathrm{F}=$ 0,74; P=0,39). Em observaçóes realizadas nos anos de 2010 a 2012, o beija-flor (Thalurania furcata) realizou de 20 a $100 \%$ de visitas legítimas às flores nas fases masculina e feminina, de diferentes indivíduos de $A$. obovata e, devido à sua frequência, foi considerado o potencial polinizador da espécie. Os resultados mostram que a limitada disponibilidade de polinizadores pode selecionar plantas de características florais e estratégias de reprodução que levam a um sistema reprodutivo autogâmico.

PALAVRAS-CHAVE: Autogamia, beija-flor, fenologia de floração, morfologia floral 


\section{INTRODUCTION}

The family Lamiaceae (Labiatae) is often considered closely related to Verbenaceae, since both have aromatic oils and ovaries with four locules due to the development of false septa (Judd et al. 2009). Amasonia comprises herbs, subshrubs and shrubs with alternate, rarely sub-opposite leaves, cymose inflorescences, cymules subtending colorful bracts and yellowish or white flowers (Judd et al. 2009).

Studies on reproductive traits of Amasonia are scarce. Some of them include a taxonomic study on Amasonia found in Brazil (Santos et al. 2012) and lists and identification keys for the genera of Lamiaceae native to the Brazilian Amazon (Harley 2012). The reproductive biology of Amasonia campestris was studied in Venezuela (Ramírez 2007) and was described as a perennial herb, with red floral bracts, yellow tubular flowers; didynamous stamens and bifid stigma, pollinated by hummingbirds and butterflies. The flowers are protandric, which means that the male sexual phase precedes the female phase (Harder and Barrett 2006).

Changes from cross-breeding to selfing have received much attention due to their biological importance for plant populations (Goodwillie et al. 2005). In altered environments, the level of disturbance of the plant-pollinator interactions and the resulting limitations for pollen export and deposition can generate different selective forces in the plant mating systems (Morgan and Wilson 2005). Eckert et al. (2010) in metaanalysis of 22 studies involving 27 plant species showing a significant reduction in the proportion of seeds outcrossed in response to anthropogenic habitat modifications.

Subtle variations in the morphology of male and female sex organs can cause significant differences in the probability of spontaneous selfing and can be important selection targets (Goodwillie et al. 2005; Eckert et al. 2010). Autogamy can generally be achieved by changes in the development of key floral traits that separate the sexual organs (anthers and stigma) in relation to space (herkogamy), time (dichogamy) or both (Schoen 1982, Wyatt 1986). The reduction in the distance between anthers and stigmas has been considered a major adaptive change towards a greater capacity for autonomous seed production, especially when plants are affected by limitations caused by cross-pollination (Herlihy and Eckert 2002; Moeller and Geber 2005; Brys and Jacquemyn 2012).

Dichogamy is a reproductive strategy to avoid intrafloral interference between pollen donation and reception (Bertin and Newman 1993). In case of complete dichogamy, selfpollination is totally impaired (Webb and Lloyd 1986), but an overlapping in the expression of the two sexual functions (i.e., partial dichogamy) can generate opportunities for selfpollination (Schoen and Lloyd 1992). Small changes in the level of dichogamy can result in major changes in the ability of self-pollination (Webb and Lloyd 1986; Barrett 2003; Kalisz et al. 2012).

This study aimed to investigate the reproductive biology and herkogamy of Amasonia obovata, providing information on the floral characteristics that explain the timing of the sexual functions, functioning of the reproductive system and the frequency of pollinators.

\section{MATERIALS AND METHODS}

\section{Studied species and study area}

Amasonia obovata Lamiaceae (Labiatae) is a subshrub to shrub (0.3-2.5m height), with brown subquadrangular branches. Leaves are usually clustered in the upper part of the branches. Inflorescences are pauciflora to multiflora, have rosy red, glabrous bracts; campanulate, chartaceous; a vinaceous calyx, light orange corolla, with lengthwise cream stripes; stamens inserted in the corolla tube. The species occurs in Venezuela (Moldenke 1947, 1978) and Brazil (in the states of Amazonas, Pará, Piauí, Tocantins and Mato Grosso), on stony soils as well as in Cerrado regions (in Piauí and Mato Grosso). Flowering season occurs between August and January and fruit ripening in September (Santos et al. 2012).

Amasonia obovata was studied in the understory of a forest fragment (ca. 18 ha) of semi-deciduous vegetation (Sassaki et al. 2010), in Tangará da Serra (14\%04' S-5703' W), in southwestern Mato Grosso, for three reproductive seasons: from December 2009 to March 2010, December 2010 to May 2011 and from December 2011 to March 2012. The study site is located at an altitude of about 420 masl and has a rainy tropical, hot and humid climate, with two seasons: a rainy season between September and April and a dry season between May and August. The average annual rainfall is 1,830 $\mathrm{mm}$. The average annual temperature is $24.4{ }^{\circ} \mathrm{C}-26.1{ }^{\circ} \mathrm{C}$ and the relative humidity $70-80 \%$ (Martins et al. 2010).

The soils of the region are sandy-clay, dystrophic or have low fertility. Currently, the original vegetation of the region is fragmented, surrounded by large monoculture areas of corn and soybean.

\section{Phenology of flowering and fruiting}

For phenological studies, 15 fertile plants were identified, numbered and monitored weekly during the flowering and fruiting periods of the species from 2009 to 2011. For each plant, the following characteristics were recorded: inflorescence length, total number of flowers per inflorescence, number of flowers per bract, number of open flowers per inflorescence/ day, the development period (in months) and fruit dispersal.

A voucher specimen was deposited at the Herbarium TANG 1104 of the Universidade do Estado de Mato Grosso 
(UNEMAT) and Laboratory of Plant Taxonomy LATAX of the Universidade Federal Rural de Pernambuco (UFRPE).

\section{Morphology and floral biology}

The morphological description was based on schematic drawings of 10 flowers of different plants.

To investigate the male and female functions for floral longevity, plants of $A$. obovata were transferred to pots and moved to a greenhouse and the gender identification confirmed by field observations. We investigated the time of flower opening, anther dehiscence, stigma receptivity, and pollen viability during the following stages of flower development: (1) pre-anthesis, (2) early anthesis, (3) first day after flower opening, (4) second day after flower opening, and (5) senescence. These parameters were evaluated every $3 \mathrm{~h}$ for four consecutive days in 25 flowers of five different plants.

The stigmatic receptivity was tested by applying 3\% hydrogen peroxide (Dafni 1992) in the morning to preanthesis buds $(\mathrm{N}=7)$ and flowers in the male $(\mathrm{N}=16)$ and female $(\mathrm{N}=12)$, and in the afternoon to flowers in the male $(\mathrm{N}=12)$ and female stages $(\mathrm{N}=9)$.

The volume of accumulated nectar was measured in flowers previously isolated in organza bags, in the male $(\mathrm{N}=14)$ and female stage $(\mathrm{N}=10)$. The test was performed at 9:00 and 15:00, using a micropipette. Pre-anthesis buds were tested for pollen viability $(\mathrm{N}=15)$ of male $(\mathrm{N}=10)$ and female-stage flowers $(\mathrm{N}=10)$ of five different plants. All anthers of buds and flowers were ground on a slide with a drop of Acetic Carmine (Radford et al. 1974) to count out 200 pollen grains (viable and non-viable) per slide under an optical microscope (SZX12, Olympus, Ontario, NY) (Koch et al. 2010).

\section{Flower and fruit morphometry}

To assess the level of herkogamy (minimum distance between stigma and anthers), 25 fresh, fully developed flowers from five plants were evaluated using graph paper and a stereoscopic microscope (S6D, Leica, Taiwan, China). The length of the following flower organs was measured: bract, calyx, corolla tube, corolla lobes, upper and lower filament, anthers, style, and stigma. In fruits $(\mathrm{N}=25)$ the height and width of mature fruits of five plants were measured, using calipers.

\section{Breeding system}

The reproductive system and number of fruits/treatment were evaluated in January and February 2012, by the following pollination treatments: spontaneous selfing $(\mathrm{N}=$ 26) (isolated flowers in organza bags, unmanipulated); handselfing $(\mathrm{N}=22)$ (isolated flowers and hand-pollinated with the plant's own pollen or flowers of the same inflorescence); apomixis $(\mathrm{N}=26)$ (isolated flowers and hand-emasculated pre-anthesis anthers), cross-pollination $(\mathrm{N}=26)$ (isolated flowers and hand-pollinated with pollen from flowers of other plants) and natural conditions $(\mathrm{N}=30)$ (flowers naturally pollinated by pollinators).

The index of self-incompatibility (ISI) was calculated by dividing the fruit/flower ratio from hand-pollination by the fruit/flower ratio from hand cross-pollination (Zapata and Arroyo 1978). Samples with indices above 0.75 were described as self-compatible (Bullock 1985).The natural fruit set was evaluated in the inflorescences destined for phenological observations. The number of fruits/inflorescence $(\mathrm{N}=15)$ and seeds per fruit $(\mathrm{N}=25)$ of these inflorescences was counted.

Data analysis. To meet the assumptions of parametric analysis, the pollen grain viability was square root transformed as required (Zar 1999). To analyze the reproductive system was conducted chi square test. The morphometric variables of A. obovata was analyzed using mean and standard deviation. All analyzes were run using Statistica software V.12 (StatSoft 2012).

\section{Floral visitors}

Diurnal flower visitors of the same set of plants $(\mathrm{N}=15)$ were monitored during the flowering peak of the species, from 2009 to 2012, in the periods of highest pollinator activity in the study area, i.e., from 05:30 to 10:30 am, and from 3:00 to 5:00 $\mathrm{pm}$, during three to five consecutive days, totaling 40 hours of observation. Observations of the visitor behavior were recorded every day and the collected floral resources were registered.

Insect visitors were collected, killed and prepared on entomological pins for later identification. Hummingbirds were observed and photographed for identification in the field with the help of a field guide (Sigrist 2007).

\section{RESULTS}

\section{Flowering and fruiting phenology}

In the study area, $A$. obovata individuals were about one meter tall and had showy inflorescences with a length of 8.1 to $29.2 \mathrm{~cm}$ (mean of $=15.09 \pm 5.60 \mathrm{~cm}$ ). During the dry season, the aerial parts of the plants dry out and restart vegetative and reproductive development at the beginning of the following rainy season.

The flowering of $A$. obovata in the first reproductive season began in the second fortnight of December and lasted until mid-March, with a flowering peak in January and February (Figure 1). The second reproductive season lasted five months (Figure 1), characterized by a longer period of flowering and greater availability of flowers (Table 1 ).

Flowering and fruiting $(\mathrm{N}=15)$ plants would occur simultaneously and last four to five months. Dispersal occurred when the fruits turned dark red, about five months after the 
Table 1. Mean and standard deviation (SD) of the total number of flowers produced per inflorescence, flowers per bracts and open flowers per day in two reproductive seasons of Amasonia obovata, in Tangará da Serra, state of Mato Grosso, Brazil

\begin{tabular}{lcccccc}
\hline Observation period & \multicolumn{3}{c}{$2009 / 2010$} & & \multicolumn{2}{c}{$2010 / 2011$} \\
\hline Analyzed parameters & Mean & SD & Range & Mean & SD & Variation \\
Flowers/ inflorescence & 53.63 & 12.32 & $30-74$ & 74.33 & 36.02 & $30-159$ \\
Flowers/ bracts & 5.55 & 1.75 & $3-9$ & 5.27 & 1.67 & $3-9$ \\
Open flowers / inflorescence/day & 3.21 & 1.82 & $1-7$ & 4.12 & 36.02 & $1-13$ \\
\hline
\end{tabular}

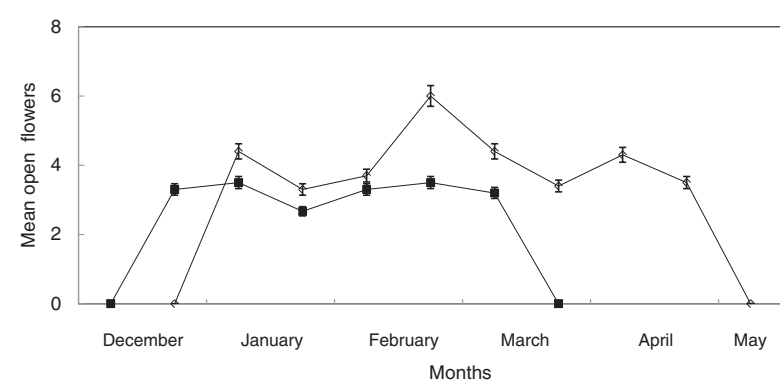

Figure 1. Flowering phenology of Amasonia obovata during the first ( $\mathbf{m})$ and second $(\diamond)$ reproductive season (2009/2010 and 2010/2011 respectively), in a forest fragment of Tangará da Serra, state of Mato Grosso, Brazil

Table 2. Morphometric variables, means and standard deviation (SD) of floral structures $(\mathrm{N}=25)$ of Amasonia obovata in a forest fragment of Tangará da Serra, state of Mato Grosso, Brazil

\begin{tabular}{lcc}
\hline Structures & Mean & SD \\
\hline Length $(\mathrm{cm})$ & & \\
Bracts & 1.83 & 0.54 \\
Calyx & 0.92 & 0.08 \\
Corolla tube & 2.95 & 0.18 \\
Corolla lobes & 0.47 & 0.09 \\
Height (cm) & & \\
Upper filament & 2.79 & 0.33 \\
Lower filament & 2.55 & 0.38 \\
Anther & 0.25 & 0.05 \\
Style & 3.06 & 0.29 \\
Stigma & 0.10 & 0.01 \\
Ovary & 0.2 & - \\
\hline
\end{tabular}
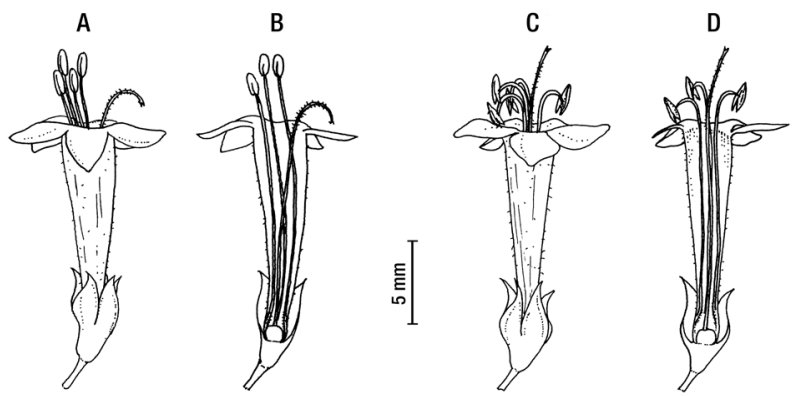

Figure 2. Position of stamens and pistil of Amasonia obovata. Male phase (A and $B$ ) and Female phase ( $C$ and $D)$, in a forest fragment of Tangará da Serra, state of Mato Grosso, Brazil beginning of fruit set. In the second half of June, branches and leaves dried out in the dry season in both observation periods. The resumption of vegetative growth was indicated by the growth of new leaves and occurred in October in 2010 and 2011. The growth of the first inflorescences was observed in late December and early January of the respective years.

\section{Morphology and floral biology}

Flowers of $A$. obovata are androgynous and protandrous, have red bracts, cream-yellow corolla, superior ovary (Table 2) with four locules and 3-4 ovules per ovary. The fresh fruits are globose and have a width of $0.5-0.7 \mathrm{~cm}$ (mean of $=0.6$ \pm 0.09 ) and height of $0.6-0.8 \mathrm{~cm}$ (mean of $=0.7 \pm 0.07$ ).

In both, buds and flowers of $A$. obovata, the floral tube opening is faced downward or perpendicular to the floral axis. There was no stigmatic receptivity or pollen release in pre-anthesis buds, however $69 \%$ of the pollen in the anthers were viable. Anthesis began in the night, around 11:30 pm, characterized by a slow detachment of lobes from the corolla. About nine hours after the onset of anthesis, the lobes of the corolla and style were exposed and reflexed.

On the first day of flower opening, the male function was evidenced by the upright position of the stamens (Figure 2AB). Stigmatic receptivity at this stage was noted in $38 \%$ and $18 \%(\mathrm{~N}=16)$ of the flowers in the morning and afternoon, respectively. Pollen release was observed in $75 \%$ of the flowers in the morning, and $100 \%(\mathrm{~N}=16)$ in the afternoon. Pollen viability was $52 \%(\mathrm{~N}=10)$. The nectar accumulated at the base of the corolla tube and the volume produced per flower was mean of $=0.56 \pm 0.36 \mu \mathrm{L}$ in the morning and mean of $=0.45 \pm 0.30 \mu \mathrm{L}$ in the afternoon. The male function lasted approximately 12 hours. During the transition from male to female function, style and anthers were upright.

The female function was evidenced between 8:00 and 10:00 pm of the first day of anthesis, characterized by the reflexed anthers and upright style and stigma (Figure 2CD). At this stage, the stigmatic receptivity was $100 \%$ in the morning and afternoon $(\mathrm{N}=12)$. Pollen was released from $33 \%(\mathrm{~N}=12)$ of the examined flowers in the morning and $56 \%(\mathrm{~N}=9)$ in the afternoon. Pollen viability was $53 \%$ $(\mathrm{N}=10)$. The nectar volume produced per flower was (mean of $=0.39 \pm 0.22 \mu \mathrm{L}$ in the morning) and (mean of $=0.20$ 
Table 3. Reproductive system of Amasonia obovata (Lamiaceae) in a forest fragment of Tangará da Serra, state of Mato Grosso, Brazil. № denotes Number.

\begin{tabular}{lcccc}
\hline Treatments & No. of flowers & No. of fruits & $\begin{array}{c}\text { Fruit set } \\
\%\end{array}$ & $\begin{array}{c}\text { Seeds/fruit } \\
\text { (Mean and SD) }\end{array}$ \\
\hline Hand self-pollination & 22 & 7 & 31.81 & $2.67 \pm 0.52$ \\
Spontaneous self-pollination & 25 & 1 & 4.00 & $2.00 \pm 0.40$ \\
Cross-pollination & 26 & 09 & 34.61 & $2.60 \pm 0.52$ \\
Natural conditions & 30 & 24 & 80.00 & $2.13 \pm 0.61$ \\
Apomixis & 26 & 0 & 00.00 & $0.00 \pm 0.00$ \\
\hline
\end{tabular}

$\pm 0.32 \mu \mathrm{L}$ in the afternoon). The female function lasted approximately 23 hours. The proportion of flowers with male and female function per inflorescence was 1:1 (mean of $=0.75$ \pm 2.1 ). Senescence, characterized by a loss of brightness and corolla drop occurred about 44 hours after the beginning of anthesis.

\section{System and reproductive success}

The fruit set rate obtained by hand-pollination did not differ from values obtained for cross-pollination $\left(X^{2}=2.81 ; p=\right.$ 0.93 , Table 3 ) and was significantly lower than under natural conditions $\left(X^{2}=9.40 ; p=0.002\right.$, Table 3$)$. No autonomous apomixis was observed in the species. The average numbers of seeds per fruit in all treatments except apomixis were similar (Table 3). The self-compatibility index was 0.77 .

The number of fruits per inflorescence ranged from 5 to 53 (mean of $=17.27 \pm 14.25$ ), averaging $1.76 \pm 0.93$ seeds per fruit. One seed was recorded in $52 \%$ of the fruits analyzed, $24 \%$ of the fruits had two seeds, $20 \%$ three and $4 \%$ four seeds (i.e., the full potential).

\section{Flower visitors}

A hummingbird Thalurania furcata (Gmelin) Trochilidae accounted for $60 \%, 20 \%$ and $100 \%$ of the visits to $A$. obovata flowers in 2010, 2011 and 2012, respectively. This hummingbird performed legitimate visits to flowers in the male and female phases of different plants. The months of greatest frequency of visits of $T$. furcata were January and February and were mostly concentrated in the morning, in the three years of observation. The foraging strategy used by T. furcata was traplining (sensu Linhart 1973). The visits last about two seconds during which the reproductive organs were touched. The interval between two consecutive visits was about one hour. In view of the visitation frequency (Total $\mathrm{N}=46$ ) and ability to perform legitimate pollinations, T. furcata was considered the only pollinator of $A$. obovata.

The bees Eulaema nigrita (Lepeletier) and Trigona were recorded in two years of observation, and together represent $22 \%$ (Total $\mathrm{N}=13$ ) of the visits to $A$. obovata. They pierced the base of the corolla tube to capture nectar, stayed in the flower for about five seconds, and visited other flowers on the same and on other plants on dry and sunny days. Ants of the genus
Ectatoma were also observed on the inflorescences, possibly due to the presence of nectaries in the calyces and at the base of the floral bracts, and were sometimes also observed at the base of the corolla tube colleting nectar, although it was not clear whether they pierced the corolla tube or used the hole made by bees.

\section{DISCUSSION}

The flowering and fruiting season of Amasonia obovata is concentrated in a period of four to five months and during the rain season, characterizing it as a hemicryptophytic species. Herbaceous hemicryptophyte species are common in the Cerrado, as for example in a cerradão (woodland-savanna with closed canopy) area, in Campo Grande, MS (Assunção et al. 2011), where $59 \%$ of the species belong to this group. This adaptive trait was also detected in $A$. campestris, in the Central Llanos region of Venezuela (Ramirez 2007), and is considered an attempt to avoid the unfavorable season (Costa et al. 2007; Ramirez 2007).

The phases of dichogamy in $A$. obovata are not clearly separated, i.e., flowers with a functionally male floral architecture also retained the female functionality and vice versa. The simultaneity of the events of pollen release and stigmatic viability in both phases, combined with a pollen viability above $50 \%$, as observed in $A$. obovata and other protandrous species of Lamiaceae (e.g., Ocimum canum Amaral et al. 2007 and Ocimum campechianum - Silva 2007), reveals that both protandry and protogyny hampers, but cannot impede selfing (Dart et al 2012).

Characteristics such as the maintenance of pollen viability and release during the female phase reinforce the male fitness in $A$. obovata flowers. The pattern of resource allocation to sexual functions may represent a strategy developed by plants to improve the performance of male and female functions, regulate self-pollination levels and ensure the sexual reproduction, so that each sexual function is benefitted by the proportion of resources allocated to it (Devlin and Stephenson 1985).

The long duration of the female phase recorded in $A$. obovata is a strategy to increase the availability for visits and maximize the reproductive success. However this pattern 
does not seem to be repeated in others markedly protandrous species such as Ferdinandusa speciosa (Rubiaceae) (Castro and Oliveira 2001) and Ziziphus joazeiro (Rhamnaceae) (Nadia et al. 2007), which have a similar longevity of male and female phases. In Salvia sellowiana (Lamiaceae), the larger male reproductive success was attributed to the anthesis longevity, gradual pollen distribution, small number of eggs to be fertilized, high frequency and foraging mode of its pollinators (Aximoff and Freitas 2010).

Although nectar was constant in both phases of $A$. obovata flowers, the volume can be considered small compared to $A$. campestris, which produced a total volume of nectar during the floral lifespan of 8.55-35.15 $\mu \mathrm{L}$ per flower (Ramírez 2007), i.e., 30 times more than in A. obovata.

The level of herkogamy of $A$. obovata can promote the selfcompatibility. The herkogamy levels of $A$. obovata flowers in the study area were lower (42\%) than recorded for the same species when using herbarium material (Santos et al 2012). This suggests that the reduced space between stigmas and anthers is at least partially responsible for the self - pollination rate of the species.

Self-fertility in inhospitable environments also may be increased in some species through a change in flower development, a common change is a reduction of herkogamy (Levin 2012).This finding corroborates a number of studies that showed that variation in herkogamy levels significantly affected autonomous reproduction (Takebayashi and Delph 2000; Herlihy and Eckert 2007; Brys and Jacquemyn 2012).

This study showed a partial protandry of $A$. obovata flowers, which means that pollen release occurs simultaneously with stigmatic viability, although the stigma is reflexed, exposing the corolla. A possible spontaneous selfing in $A$. obovata can happen at the transition from male to female function, when the stigma assumes an upright position together with the anthers.

Self-compatibility was also recorded in other protandrous species such as Cuphea melvilla (Lythraceae) (Melazzo and Oliveira 2012) Ocimum canum (Amaral et al. 2007) A. campestris (Ramírez 2007) and ornithophilous species (Castro and Oliveira 2001; Araujo and Oliveira 2007; Ramírez 2007, Aximoff and Freitas 2010). The autogamy of $A$. obovata seems advantageous, in view of the history of deforestation and strong anthropogenic pressure in the study area.

The results of the pollination treatments of Amasonia obovata were analogous to those registered for $A$. campestris (Ramírez 2007) and Anadenanthera peregrina (Fabaceae) (Costa et al. 2003), which are protandrous species, where the higher percentage of fruit set and seed production is a result of cross- and natural pollination.
The number of fruits per inflorescence produced in $A$. obovata was lower than recorded in natural pollination of $A$. campestris, (mean of $=28.86$ fruits per inflorescence and mean of $=2.98$ seeds/fruit) (Ramírez 2007). The low four seeded fruit set in $A$. obovata can be related to the limited availability of pollinators, since in these fruit the abortion of the other ovules and breaking of the self-incompatibility barrier was observed, preceded by the overlapping of the male and female phases. In Vitex megapotamica (Lamiaceae), $88 \%$ of the fruits formed only one seed, $8 \%$ had two and $4 \%$ formed only atrophied seeds (Cosmo et al. 2009).

The only species recorded pollinating $A$. obovata flowers, in three years of observation, was the male hummingbird Thalurania furcata. However, our field observations may be underestimated since the nocturnal floral visitors were not observed. For Helicteres lhotzkyana, T. furcata was considered an infrequent pollinator, performing $18 \%$ of the visits (Silva et al. 2010), in the same study area. Three hummingbirds and four diurnal moth species were recorded as major pollinators of Amasonia campestris (Ramírez 2007). Although not considered pollinator, the presence of ants on branches and flowers was also recorded for Ocimum canum (Lamiaceae) (Amaral et al. 2007).

The behavior of the pollinator to visit all open flowers can increase the self-pollination rates by geitonogamy, as in A. obovata a balanced proportion of flowers in the male and female phases in the same inflorescence was observed. A low number of pollinators associated to nectar production may compromise the reproductive success (Pyke 1991), as observed for A. obovata, which may influence the decision of the pollinator with regard to the choice of flowers or flower groups (Leiss and Klinkhamer 2005).

Studies have shown that the absence of pollinators and a limited pollen flow can generate selective forces in plant breeding systems (see, for example, Morgan and Wilson, 2005; Eckert et al. 2010). In situations of severe pollen limitation it is expected that selective forces act on floral traits, e.g., reductions in the level of herkogamy or dichogamy (Cruden and Lyon 1989, Morgan and Wilson 2005; Porcher and Lande 2005) promoting autogamy and ensuring the reproductive success (Dart et al 2012).

On the other hand, when spontaneous self-fertilization evolves, a reduction in the investment for pollinator attraction is expected, e.g., reductions in the flower size, corolla diameter, number of flowers, floral longevity, etc. and compensations such as a reduction in the nectar volume or pollen production (Ornduff 1969; Eckert et al. 2010). Detailed studies of the floral morphology and functioning of the mating system also showed that plants at sites with poor pollinator frequency had twice as much chances of spontaneous self-fertilization as pollinator-rich locations (Brys et al. 2013). Studies on floral 
traits and reproductive systems within and among other $A$. obovata populations are required to elucidate adaptations of species to environmental conditions.

\section{CONCLUSIONS}

The partial dichogamy of $A$. obovata flowers is evidenced by the concomitant expression of sexual functions in the male and female phases. The autogamy of $A$. obovata may be related to a reduction in the levels of herkogamy, and the low rate fruits set with four seeds to the limitation of pollinators. In the three years of observation, Thalurania furcata was the only pollinator observed visiting $A$. obovata flowers in the study area. Additional studies about the distribution of species are needed to clarify or test this herkogamy reduction.

\section{ACKNOWLEDGEMENTS}

The authors wish to thank Juliana Santos (Universidade Federal Rural de Pernambuco) for identifying the species and the anonymous reviewers for their criticisms and suggestions for improvements of the manuscript. Financial support was provided by the Fundação de Pesquisa do Estado de Mato Grosso (FAPEMAT), grant number 296039/2010.

\section{REFERENCES}

Amaral, C.L.F.; Almeida, O.S.; Silva, A.B.; Brito, A.C. 2007. Tendências evolutivas de Ocimum canum Sims (Lamiaceae) subsidiando programas de melhoramento genético. Diálogos e ciência, 12: 1-11.

Araujo, F.P.; Oliveira, P.E. 2007. Biologia floral de Costus spiralis (Jacq.) Roscoe (Costaceae) e mecanismos para evitar a autopolinizacao. Revista Brasileira de Botânica, 30: 59-67.

Assunção, V. A.; Guglieri-Caporal, A.; Sartori, A. L. B. 2011. Florística do estrato herbáceo de um remanescente de Cerradáo em Campo Grande, Mato Grosso do Sul, Brasil. Hoehnea, 38: 281-288.

Aximoff, I.A.; Freitas, L.2010. Is pollen removal or seed set favoured by flower longevity in a hummingbird-pollinated Salvia species?. Annals of Botany, 106: 414-419.

Barrett, S.C.H. 2003. Mating strategies in flowering plants: The outcrossing-selfing paradigm and beyond. Philosophical Transactions of the Royal Society of London, B, Biological Sciences, 358 : 991-1004

Bertin, R.I.; Newman C.M. 1993. Dichogamy in Angiosperms. Botanical Review, 59: 112-152.

Brys, R.; Geens, B.; Beeckman, T.; Jacquemyn, H. 2013. Differences in dichogamy and herkogamy contribute to higher selfing in contrasting environments in the annual Blackstonia perfoliata (Gentianaceae). Annals of Botany, 111: 651-661.

Brys, R.; Jacquemyn, H. 2012. Effects of human-mediated pollinator impoverishment on floral traits and mating patterns in a short-lived herb: an experimental approach. Functional Ecology, 26: 189-197.

Bullock, S.H. 1985. Breeding systems in the flora of a tropical deciduous forest. Biotropica, 17: 287-301.
Castro, C.C.; Oliveira, P.E.A.M. 2001. Reproductive biology of the protandrous Ferdinandusa speciosa Pohl (Rubiaceae) in southeastern Brazil. Revista Brasileira de Botânica, 24: 167-172.

Cosmo, N.L.; Gogosz, A.M.; Nogueira, A.C.; Bona, C.; Kuniyoshi, Y.S. 2009. Morfologia do fruto, da semente e morfo-anatomia da plântula de Vitex megapomica (Spreng.) Moldenke (Lamiaceae) Acta Botanica Brasilica, 23: 389-397.

Costa, R.B.; Contini, A.Z.; Melo, E.S.P. 2003. Sistema reprodutivo de Anadenanthera peregrina (L.) Speg e Vochysia haenkiana (Spreng.) Mart. em fragmento de cerrado na Chapada dos Guimarães - MT. Ciência Rural, 33: 305-310.

Costa, R.C.; Araújo, F.S.; Lima-Verde, L.W. 2007. Flora and life-form spectrum in an area of deciduous thorn woodland (caatinga) in northeastern, Brazil. Journal of Arid Environments, 68: $237-247$.

Cruden, R.W.; Lyon, D.L. 1989. Facultative xenogamy: examination of a mixed mating system. In: Bock, J. e Linhart, Y.B. (Eds.). Evolutionary Ecology of Plants. Boulder, Westview Press. p. 171-207.

Dafni, A. 1992. Pollination Ecology - A Practical Approach. Oxford, Oxford University Press. 260p.

Dart, S.R.; Samir, K.E.; Austen, E.; Eckert, C.G. 2012. Broad geographic covariation between floral traits and the mating system in Camissoniopsis cheiranthifolia (Onagraceae): multiple stable mixed mating systems across the species' range?. Annals of Botany, 109: 599-611.

Devlin, B.; Stephenson A.G. 1985. Sex differential floral longevity, nectar secretion, and pollinator foraging in a protandrous species. American Journal of Botany, 72:300-310.

Eckert, C.G.; Kalisz, S.; Geber, M.A.; Sargent, R.; Elle, E.; Cheptou, P.O.; Goodwillie, C.; et. al. 2010. Plant mating systems in a changing world. Trends in Ecology and Evolution, 25: 35-43.

Goodwillie, C.; Kalisz, S.; Eckert, C.G. 2005. The evolutionary enigma of mixed mating systems in plants: Occurrence, theoretical explanations, and empirical evidence. Annual Review of Ecology Evolution and Systematics, 36: 47-79.

Harder, L.D.; Barrett, S.C.H. 2006. Ecology and evolution of flowers. New York, Oxford University Press.

Harley, R.M. 2012. Checklist and key of genera and species of the Lamiaceae of the Brazilian Amazon. Rodriguésia, 63: 129-144.

Herlihy, C.R.; Eckert, C.G. 2002. Genetic cost of reproductive assurance in a self-fertilizing plant. Nature, 416: $320-323$.

Herlihy C.R.; Eckert, C.G. 2007. Evolutionary analysis of a key floral trait in Aquilegia canadensis (Ranunculaceae): genetic variation in herkogamy and its effect on the mating system. Evolution, 61: 1661-1674.

Judd, W.S.; Campbell, C.S.; Kellogg, E.A.; Stevens, P.F.; Donoghue, M.J. 2009. Sistemática vegetal: um enfoque filogenético. 3 ed. Porto Alegre, Artmed.576p.

Kalisz, S.; Randle, A.; Chaiffetz, D.; Faigeles, M.; Butera, A.; Beight, C. 2012. Dichogamy correlates with outcrossing rate and defines the selfing syndrome in the mixed-mating genus Collinsia. Annals of Botany, 109:571-582. 
Koch, A.K.; Silva, P.C.; Silva, C.A. 2010. Biologia Reprodutiva de Psychotria carthagenensis (Rubiaceae), espécie distílica de fragmento florestal de mata ciliar, Centro-Oeste do Brasil. Rodriguésia, 61: 551-558.

Leiss, K.A.; Klinkhamer, P.G.L. 2005. Spatial distribution of nectar production in a natural Echium vulgare population: Implication for pollinator behavior. Basic and Applied Ecology 6: 317-324.

Levin, D. A. 2012. Mating system shifts on the trailing edge. Annals of Botany, 109: 613-620.

Linhart, Y.B. 1973. Ecological and behavioral determinants of pollen dispersal in hummingbirds-pollinated Heliconia. American Naturalist, 107: 511-523.

Martins, J.A.; Dallacort, R.; Inoue, M.H.I.; Santi, A.; Kolling, E.M.; Coletti, A.J. 2010. Probabilidade de precipitaçáo para a microrregião de Tangará da Serra, Estado de Mato Grosso. Pesquisa Agropecuária Tropical, 40: 291-296.

Melazzo, A. F.; Oliveira, P.E. 2012. Cuphea melvilla Lindlay (Lythraceae): uma espécie do Cerrado polinizada por beija-flores. Acta Botanica Brasilica, 26: 281-289.

Moeller, D. A.; Geber, M. A. 2005. Ecological context of the evolution of self-pollination in Clarkia xantiana: Population size, plant communities, and reproductive assurance. Evolution; International Journal of Organic Evolution, 59: 786-799.

Moldenke, H.N. 1947. Notes on the genus Amasonia II. In: Gleasson, H.A. e Moldenke, H.N. (eds.). Phytologia, 2: 246-247.

Moldenke, H.N. 1978. Notes on the genus Amasonia VII. In: Gleasson, H.A. e Moldenke, H.N. (eds.). Phytologia, 40: 403-406.

Morgan, M.T.; Wilson, G.M. 2005. Self-fertilization and the escape from pollen limitation in variable pollination environments. Evolution, 59: 1143-1148.

Nadia, T.L.; Machado, I.C.; Lopes, A.V. 2007. Fenologia reprodutiva e sistema de polinização de Ziziphus joazeiro Mart. (Rhamnaceae): atuação de Apis mellifera e de visitantes florais autóctones como polinizadores. Acta Botanica Brasilica, 21: 835-845.

Ornduff, R. 1969. Reproductive biology in relation to systematics. Taxon, 18:121-123.

Porcher, E.; Lande, R. 2005. The evolution of self-fertilization and inbreeding depression under pollen discounting and pollen limitation. Journal of Evolutionary Biology, 18: 497-508.

Pyke, G.H. 1991. What does it cost a plant to produce floral nectar? Letters to Nature, 350:58-59.
Radford, A. E.; Dickson, W.C.; Massey, J.R.; Bell, C.R. 1974. Vascular plants systematic. New York, Harper e Row. 891p.

Ramírez, N. 2007. Biología reproductive de Amasonia campestris (aubl.) Moldenke (Verbenaceae) en los llanos Centrales de Venezuela. Acta Botanica Venezuelana, 30: 385-414.

Santos, J.S.; França, F.; Silva, M.J.; Sales, M.F. 2012. Levantamento das espécies de Amasonia (Lamiaceae) para o Brasil. Rodriguésia, 63: 1101-1116.

Sasaki, D.; Zappi, D.; Milliken, W.; Henicka, G.S.; Piva, J.H. 2010. Vegetação e plantas do Cristalino-um manual. São Paulo, Viena Gráfica e Editora. 127p.

Schoen, D.J. 1982. The breeding system of Gilia achilleifolia: variation in floral characteristics and outcrossing rate. Evolution, 36: $352-360$

Schoen, D.J.; Lloyd, D.G. 1992. Self and cross fertilization in plants. III. Methods for studying modes and functional aspects of selffertilization. International Journal of Plants Science, 153:381-393.

Sigrist, T. 2007. Aves do Brasil Oriental. São Paulo, Avis Brasilis. 448p.

Silva, A.B. 2007. Biologia reprodutiva e citogenética da Alfavaca do Campo (Ocimum campechianum Mill.). Dissertação de Mestrado. Universidade Estadual do Sudoeste da Bahia, Jequié - Bahia.63p.

Silva, C.A.; Ferreira, D.S.; Koch, A. K.; Araújo-Silva, L.E. 2010. Variação na arquitetura floral e sucesso reprodutivo de duas espécies de Helicteres (Malvaceae), na região Sudoeste de Mato Grosso. Acta Botanica Brasilica, 24: 462-468.

StatSoft INC. 2012. Statistic for Windows (Computer Program Manual). StatSoft Inc., Tulsa.

Takebayashi, N.; Delph, L.F. 2000. An association between a floral trait and inbreeding depression. Evolution, 54: 840-846.

Webb, C. J.; Lloyd, D. G. 1986. The avoidance of interference between the presentation of pollen and stigmas in Angiosperms. II. Herkogamy. New Zealand Journal of Botany, 24: 163 -178.

Wyatt, R. 1986. Ecology and evolution of self-pollination in Arenaria uniflora (Caryophyllaceae). Journal of Ecology, 74: 403-418.

Zapata, R.T.; Arroyo, M.T.K. 1978. Plant reproductive ecology of a secondary deciduous forest in Venezuela. Biotropica, 10: 221-230.

ZAR, J.H. Biostatistical analysis. 1999. New Jersey, Prentice Hall. 662p.

Recebido em 07/11/2013

Aceito em 08/04/2014 